\title{
LA IMPORTANCIA DE LA MÚSICA EN LA SALUD DE LA POBLACIÓN EN TIEMPOS DE PANDEMIA COVID 19
}

\author{
The importance of music in the health of the population in times of Covid 19 pandemic
}

Héctor William Carlos Cruces ${ }^{1}$

${ }^{1}$ Docente de la Facultad de Ciencias Económicas y Negocios Internacionales de la Universidad Nacional "San Luis Gonzaga"

\section{Sr. Editor}

He leído el artículo científico titulado "Efectividad del programa "Melodías de Cuidar", en el manejo de la ansiedad en usuarios preoperatorios del servicio de cirugía del hospital Félix Mayorca Soto, Tarma - 2019"(1), es muy interesante y relevante en estos momentos de crisis que atraviesa el mundo y por ende el Perú ,por la pandemia ocasionada por el coronavirus COVID-19 estando de acuerdo con el autor respecto a la efectividad del programa "melodías de cuidar" en el manejo de la ansiedad en las dimensiones la cognitiva, conductual y fisiológico, se atribuye otros factores como el espiritual, biológico, psicológico.

Las personas experimentan diferentes emociones como congoja por la pérdida de un ser querido, un empleo, y el temor constante de contraer el COVID.19, generándose en la actualidad el trastorno más común el de la ansiedad., considerándose como la primordial fisonomía de la ansiedad un intenso malestar Psicofísico (2) se refiere al temor a algo, en un contexto en la cual las personas desconocen que va acontecer y reacción, , complicando en estos tiempos de pandemia la salud mental de las personas, siendo de un manejo difícil, produciendo diferentes sintomatologías como dolor de cabeza, sensación falta de aire, malestar del cuerpo, diarreas, dolor de pecho, síntomas que en muchos casos es confundido con el COVID19 , por el cual muchas personas acuden a los hospitales, exponiéndose al inminente peligro de contagio del temido virus,

Desde épocas primitivas se usaba la música para eventos importantes como bodas, funerales, danzas, otros, en el antiguo Egipto se inició el uso de la música con fines médicos, hallándose en Kahum, Egipto en el año 2500 a.C. Hacia el año 1500 a.c. el primer escrito de la música y su influencia en el cuerpo humano, en Grecia los filósofos Platón y Aristóteles recomendaban la musicoterapia, brindando las pautas para considerarse la música como ciencia, a partir de la segunda mitad del siglo XIX, y más en concreto con el médico Rafael Rodríguez Méndez, cuando se preconiza el uso de la música como tratamiento terapéutico (Corbella y Doménech, 1987). Será otro médico y catedrático de la Universidad de Madrid, Francisco Vidal y Careta, quien en 1882 realiza la primera tesis musical que compagina la música y la medicina (3)

Existen diferentes estudios sobre la musicoterapia y su beneficios en el bienestar del ser humano, bondades que deben ser aprovechadas en la actualidad, donde el mundo no se imaginaba enfrentar la catástrofe más grande de los últimos tiempos, cambiando en el Perú todos los escenarios y demostrando lo precario de los diferentes sistemas, educación, economía siendo uno de los más afectados el de salud, donde los hospitales han colapsado, teniendo una sobrepoblación de pacientes hospitalizados y altos índices de letalidad, obligando a los gobiernos dictar medidas como cuarentenas, confinamientos, significando que gran porcentaje de la población en América Latina debe convivir en precariedad habitacional, implicando la salud mental, por lo que se debe aplicar como medicina alternativa la musicoterapia , está comprobado que las personas al 
escuchar música de su agrado el cuerpo genera una serie de hormonas responsables del placer, como la dopamina es uno de los neurotransmisores que utilizan las neuronas para comunicarse entre ellas sirve de motivación, la serotonina es la principal encargada de regular nuestro estado de ánimo, es un neurotransmisor de la felicidad, así mismo las hormonas endorfinas es un neurotransmisor producido por las glándulas pituitaria y el hipotálamo , tiene un efecto analgésico para el dolor, dando una sensación de bienestar, además este tipo de hormona es sumamente importante para reducir los cuadros de ansiedad, debiendo difundirse en todos los medios y transmitir música apropiada las emisoras de radio, televisión, cable y otros, poniendo en práctica la musicoterapia para aliviar los enfermos, y disminuir los índices elevados de cuadros de ansiedad en la población por la pandemia ocasionada por el COVID-19.

\section{CORRESPONDENCIA:}

Dr. Carlos Cruces, Héctor William

Correo Electrónico:

Hector.carlos@unica.edu.pe

\section{REFERENCIAS BIBLIOGRÁFICAS}

1. Quise I, Hinostrosa N, Condor C. Efectividad del programa "Melodías de Cuidar", en el manejo de la ansiedad en usuarios preoperatorios del servicio de cirugía del hospital Félix Mayorca Soto, Tarma. Perú 2019. Rev. Enf.Vanguard.2020; 8(2):50-58

2. Moreno Calle A. Detección y actuación en la ansiedad preoperatoria inmediata. De la teoría a la práctica. Rev. de Cirugía mayor ambulatoria Barcelona, España 2015; 20 (2): 74-78

3. Zárate P, Díaz, V. (2001). Aplicaciones de la Musicoterapia en la medicina.2001. Rev. Médica de Chile, 129(2): 219-223. (Internet) (Citado el 12 de Marzo 2021) Disponible en: http://www.scielo.cl/scielo.php?pid=S00 $3498872001000200015 \&$ script $=$ sci artte $\underline{x t}$

Recibido: 15/04/2021 